function as the main source of revenue, and the pressure of direct taxation was reduced.

This turnover tax is particularly adapted to the needs of the Soviet economy, and it can, for example, be used for facilitating or hindering the sale of a particular commodity. The effects of this tax on commodity prices are discussed in some detail by $\mathbf{M r}$. H. $\mathbf{H}$. Ware in an article in Bulletin 4 entitled "The Function and Formation of Commodity Prices in the U.S.S.R.". He points out that, by means of the planned application of this tax, the retail prices of different consumer goods are adjusted to their existing and future planned supplies, relative to the market pressures of consumer demand. There is no free consumer choice since only those known consumer desires which meet with official approval are incorporated into production plans. Further restrictions on the consumer are seen in the absence of price competition among shops. Price competition only takes place in the 'free markets' of the collective-farm peasants, which transact about one-fifth of the rouble volume of all Soviet trade. Consumer choice exerts some pressure, however, on retailers, wholesalers, planners and producers in that, if the consumer refuses to buy the commodities at the price offered, the plans go unfulfilled. Planned retail prices would be 'too high' relative to demand and supply if the goods failed to sell according to plan, and 'too low' if they sold out so rapidly that they could not be kept in retail stock.

During the War, Russia found herself, owing to the scarcity of food and the short supply of consumer goods, in the position of there being "too much money chasing too few goods", and rationing was introduced. Unlike the British system, this was based on differential scales according to the category of the worker and the number of hours worked. This is described in an article by Dr. Baykov on "Internal Trade", in which he states that it was also possible to buy rationed articles legally, but at much higher prices, on the free kolkhoz markets for agricultural products. In 1944, the differential system was further expanded and the sale of rationed goods in special State shops in unrestricted quantities was introduced, though the prices were much higher than those of similar goods bought on the ration cards.

Rationing was abolished in December 1947 and was accompanied by a monetary reform. Unified prices were fixed at which goods could be freely sold by State and co-operative shops.

Bulletin 4 also contains an interesting article on Russian railways by $\mathrm{Mr}$. $\mathrm{H}$. Hunter. He states that, in the initial period of industrial expansion which commenced in 1928, the railways proved capable of handling a greatly increased volume of freight traffic without much expansion of the existing facilities. By 1932 , the total route mileage operated was only 6 per cent more than that of 1928 , even though this was the period in which the Turkestan-Siberian route came into operation. By that year, however, the railways were finding it impossible to handle all the traffic that was being offered, and in 1935 the State found it necessary to increase allocations of material and labour for the purpose of increasing the capacity of the basic routes on which it was decided to concentrate the traffic. This policy of selective improvement resulted in wide disparity between the best and the worst lines of the system. The campaign for regional self-sufficiency, which was inaugurated in 1939, has been continued since the War, and there has been much pressure to eliminate cross-haul traffic and to minimize long-distance hauls. Road transport is not yet an appreciable factor in Soviet transport, and Mr. Hunter considers that its development is likely to be slow because the traffic which is being developed is that connected with the heavy industries.

The Bulletins contain a great amount of informa tion and can be recommended to all those who are seeking an objective description of the Soviet economy. It is not easy to suggest improvements ; but perhaps two points may be mentioned. The use of American terminology in some of the articles may prove confusing to British readers, and, since Soviet statistics of any value are so hard to come by, somewhat more care might be exercised in their editing; for example, the word 'milliard' in some of the tables seems to be misprinted for 'millions'.

\section{NATIONAL FUEL RESEARCH INSTITUTE OF INDIA}

$T$ HE National Fuel Research Institute of India, the plans for which were described in Nature of March 1, 1947, was opened by the President of the Republic, Dr. Rajendra Prasad, on April 22, 1950. Among those present were the Prime Minister, Pandit Jawaharlal Nehru; Sir C. V. Raman; Sir S. S. Bhatnagar ; Sir J. C. Ghosh ; Sir K. S. Krishnan ; Sir J. J. Ghandy ; Dr. J. W. McBain ; Dr. D. N. Wadia; and the chief inspector of mines, Mr. $\mathrm{N}$. Barraclough. The Governor of Bihar, His Excellency Shri M. S. Aney, presided. The Institute is situated at Jealgora, near Dhanbad, in the province of Bihar. It lies approximately 150 miles north-west of Calcutta, 65 miles north of Jamshedpur, and 5 miles only from the new fertilizer works at Sindri on the Damodar River.

The buildings consist of three main blocks, adminis. trative offices, laboratories and technological block, respectively. The administrative building is to be connected by further rooms to the main laboratory block. At present, they are separated by about fifty yards, while the technological block is two hundred yards away, in order to avoid dust clouds and fumes from the grinding and carbonizing, and other plant, and the like.

The Administrative Block faces the main Sindri road, and has a floor area of about $14,000 \mathrm{sq}$. ft. It is divided by a central corridor running the full length. The rooms immediately near the entrance hall comprise a reception room, telephone exchange, and visitors' sitting room. The rooms on the wings are those of the administrative officer and the assistant director, the director's laboratory, the director's office, and director's secretary, the board room, the general office, and the accounts office. The above rooms are on the left wing. On the right wing lie the rooms for information and statistics, offices for the chief officers of the Coal Survey, a physical laboratory, engineering drawing office, the geology and the map room, and a large library and reading room. All the rooms are air-conditioned.

The Laboratory Block has a basement, the main floor, and (above) staff common room and lecture room. On the roof there is an emergency tank for water supply. The front building is due to be connected with the Laboratory Block by a 25 -ft. covered passage, which enters into the two wings, each about $100 \mathrm{ft}$. long. These wing laboratories are planned to house rooms for fundamental research on colloids, 
chromatography, photo-chemistry, hydrocarbon synthesis, electrical and magnetic properties of coal, coal petrography, photography, spectroscopy, X-rays, gas research, microanalysis, the testing of tars, and research into liquid fuels.

The existing block contains ten laboratories. In the basement are housed the main stores, the airconditioning plant, a glass-blowing section, photostat room and studio, and the Jharia Coal Survey with its adjoining rooms. On the principal floor are rooms for service stores and standardization, chromatography and photo-chemistry, tar and by-products, inorganic analysis, general coal analysis, liquid fuel synthesis, surface chemistry, gas analysis, calorimetry, and coal constitution. There is a staff writing room. A goods hoist is provided from the basement to the main floor. On the top floor is a large room designed for lectures, conferences, and reading. There is also a canteen for light refreshments. All the rooms are air-conditioned.

The Technological Block is situated at a short distance away, as already mentioned. This arrangement not only makes for cleanliness of the main building, but is also convenient inasmuch as it facilitates the bringing of a railway siding to the Technological Block from the branch line of the Bengal Nagpur Railway, which runs to the southwest of the estate. The Technological Block contains rooms for receiving, weighing and storing coal, and for breaking, grinding, and sampling. A coal-dressing laboratory is also provided. Adjoining the coalsampling rooms are sections for coal carbonization and the testing of coke, and for studies in fluidization and pneumatic conveying. Another section is devoted to the gasification of coal and the production of oxygen, while the adjoining room is designed for experiments on Fischer-Tropsch synthesis and hydrogenation, the control room being on the verandah side. The remaining sections are allotted to $(a)$ instrument making and repair, $(b)$ power sub-station, (c) general engineering stores, and (d) engineering workshop. In the grounds adjoining the Technological Block, pilot plant for different processes such as coal-washing, pulverized fuel, and coal carbonization will be erected.

There is a small block of rooms near the main Technological Block which will serve later as the engineering offices.

Most of the laboratories are on a unit basis, each unit or room, $18 \mathrm{ft} . \times 21 \mathrm{ft}$., accommodating two research workers. This gives the necessary privacy. Each worker has one central and one side bench. The fume cupboards are large, $14 \mathrm{ft} . \times 3 \mathrm{ft} . \times 6 \mathrm{ft}$. high, and are partitioned to give one section for dangerous or obnoxious fumes, while the other serves as a working bench. The ventilation of the cupboards has been designed to avoid using the conditioned air of the rooms. Each cupboard is provided with water, gas, electricity, compressed air, and vacuum. It is lighted from above by external fluorescent lighting through the reinforeed glass top. Consequently, the cupboard is really a working bench for many purposes. The controls of all services are from the front.

The walls dividing the laboratories are comparatively light structures, easily removable, so that, should it be desired to convert two or three rooms into one large laboratory, the change can be effected with ease. The steel-framed windows are large and give adequate light. For artificial illumination tubular fluorescent lighting has been provided, giving an illumination on the benches of 12 foot-candles.
In each research laboratory (except in the basement) there is a double bench in the middle of the room, between the windows, with auxiliary benches against the walls. The framework of the benches carries the service points, which connect with the main services supplies through channels in the floors. Any bench is thus complete with its own services and, if necessary, can be removed by disconnecting at the control points, while another bench is installed with a different layout. Indeed, except for the fume cupboard, which is fixed, the layout of any laboratory can be changed entirely and reconstructed in the course of forty-eight hours, without causing stoppage of work in adjacent rooms.

Balances are provided in some laboratories, but there is also a special balance room in each block, centrally located and suitably lighted.

The laboratory services comprise water, gas, electricity, compressed air, and vacuum. Electric power points are provided in convenient positions at the front of the benches. Control is particularly easy, as the plugs also carry switches. The water, gas, compressed air, and vacuum mains run under the floors of the principal laboratories, and feed each room at convenient and appropriate positions. The large ring-main system of these supplies ensures equal pressure and equal vacuum at each tap. Each laboratory, moreover, can easily be isolated for repairs.

The water supply is from a well $15 \mathrm{ft}$. in diameter and $120 \mathrm{ft}$. deep, behind the main Laboratory Block. The water from this well is pumped into a receiver in which the pressure is developed by means of entrapped, and thus compressed, air. There is an automatic device for maintaining the necessary pressure. The system was decided upon in order to effect economy, to give water at a high pressure, and to save the construction of a water-tower.

The waste water from the laboratories passes first by lead pipes at moderately high inclination to cast. iron vertical down-comers, and then through open earthenware channels to the drains.

The gas, compressed air, and vacuum plant are housed in the rooms under the outside staircase at the tail-end of the Laboratory Block.

The framework of the laboratory benches is of aluminium alloy tubing, which is light in weight, and simple to assemble and modify. The bench tops are of teak, $1 \frac{1}{2}$ in. thick. Cupboard units can be put into position or removed as required. The benches are $2 \mathrm{ft} .10 \mathrm{in}$. high and $2 \mathrm{ft} .3 \mathrm{in}$. wide, and there is a clear space of 7 in. under each bench to provide for cleaning and to avoid troubles from dirt, corrosion, rotting, insect pests, and the like. Normally each bench carries two cupboards. This design of bench has proved highly convenient and successful. The central double benches are easily taken to pieces and remade as single benches, and odd sizes can be assembled at short notice. The framework makes it possible to carry the services conveniently, so that only few service points are required on the laboratory walls. For central 'chemical' benches front control of all services is provided.

\section{Organization}

The Fuel Research Institute conducts research into the major problems of fuel-solid, liquid and gaseous -and operates the Physical and Chemical Survey of the Coals of India. The object of this Survey is to provide a reliable assessment of the quality and quantity of the resources of the different coals of the 
country, and to ensure that the different types of coal are utilized to the best advantage-a formidable task.

In addition to problems of fundamental and applied research, technical investigations into the sampling and analysis of fuel are also undertaken at the Institute, and pilot plant developed for different processes. The following are some of the subjects with which the researches are concerned : furnaces, combustion, and boiler plant; high- and lowtemperature carbonization; coal-washing; powdered coal ; briquetting; gasification; hydrocarbon synthesis; tar hydrogenation; plastics; liquid fuels; internal combustion engine performance; smoke and atmospheric pollution.

The main Divisions of the Institute are : (1) Coal Survey and Analysis; (2) Carbonization and Byproducts ; (3) Liquid Fuel (including synthetic fuels, petroleum, and substitutes); (4) Physics (including $\mathrm{X}$-rays and spectroscopy); (5) Gaseous Fuels (including gasification); (6) Engineering (including preparation of coal for the market, coal-washing, boiler plant, combustion, engineering, etc.); (7) Library and Intelligence; and (8) Administration and Office.

At present the headquarters staff consists of the director, assistant directors, and about seventy qualified scientific men, technologists, and engineers.

The total cost of the Institute inclusive of buildings, fittings and equipment amounts to Rs. 30 lakhs. This does not include the cost of the pilot-plant, for which funds are required in the immediate future. Pilot-plant is in hand for the following: coal carbonization (high- and low-temperature); hydrocarbon synthesis from coal; pulverized fuel investigations; coal washing; hydrogenation of coal.

\section{Programme of Work}

The subjects of pressing importance are: $(a)$ physical and chemical survey of the coals of India; (b) blending of coals for coking ; (c) study of the washability of coals ; $(d)$ production of oil from coal ; (e) development and extension of the uses of powdered coal.

In order to assess the coal reserves of the country, coal survey laboratories are being established in the chief coalfields, namely, Raniganj, Jharia, BokaroRamgarh-Karanpura, Vindhya Pradesh, Madhya Pradesh, and Assam. The staff for these laboratories is first trained at the Institute. Each coal survey laboratory has a staff of eight to ten persons under the charge of a senior scientific officer. The organization and conduct of the survey involve considerable work and constitute an important part of the activities of the Institute.

India has vast supplies of iron ore. Her supplies of coking coal are, however, not over-abundant, and researches into the up-grading of coking and caking coals by mechanical coal-cleaning (that is, washing, etc.), and into the possibilities of blending for colsing are of paramount importance. Tests on coal-washability were started at the instigation of the Euel Research Committee some years ago ; and the Coal Blending and Coking Research Committee at Jamshedpur has done useful pioneer work in the past decade.

The chief consumers of coal in India are the railways, which utilize about one-third of the total output of 30 million tons of coal per annum. The Fuel Research Institute has for some years co- operated with the Railway Board in its fuel problems, chiefly in an advisory capacity.

Regarding mineral oil, India's indigenous annual production is only 7 per cent of the total consumption. Many of the above pilot-plant schemes are directly or indirectly concerned with the production of oil fuel. Work on low-temperature carbonization, on hydrogenation, and on hydrocarbon synthesis on pilot-plant scale is essential to provide the basic results on which to build commercial plant for the production of liquid fuel.

The preparation and utilization of powdered coal are also being studied. Investigations into coal and coke breakability and grinding, and into the combustion of pulverized coal under pressure conditions, are in hand. The work is connected with the potentialities of coal dust for use in gas-turbines. The nature of other researches in hand will be gathered from the list given later.

For some three years, work has been carried on in a temporary laboratory at Dhanbad, ten miles away. In this laboratory, it has been possible to make a beginning of the physical and chemical survey of the coals of India, to study the washability of many of the seams of the Jharia, Raniganj, Bokaro, and C.P. coalfields, and to undertake preliminary investigations into the carbonization of Indian coals. In addition, attention has been given to manufacturing synthetic oil by the Fischer-Tropsch process, to laying the foundations of sound sampling, analytical, and testing technique, and to training a number of fuel chemists.

In addition, several hundred samples of coal have been analysed for their physical and chemical properties; for example, screen analysis, proximate analysis, ultimate analysis (including nitrogen, sulphur and phosphorus), caking index, calorific value. For some coals, Gray-King carbonization assays of the coal and the determination of the fusion ranges of the ash have also been done. Work has been undertaken for outside parties on a payment basis to the value of approximately Rs. 10,000 per annum.

At present researches are in hand on the following subjects: studies in coal washability and densities of Indian coals, including cleaning of coal by froth flotation and the cyclone washer; coal breakage investigations ; pressurized combustion of powdered coal ; low-temperature carbonization by various methods, including fluidization; coal constitution investigations; coal-tar investigations for quality, yield, tar-acids, etc. ; hydrocarbon synthesis studies; studies in surface chemistry and the natural moisture of coals; lignite analyses, including montan wax investigations; coal petrography studies with reference to the reflectance of the vitrains ; investigations on sampling and sizing of coals; studies in the flow of air through broken coal and pneumatic conveying of coal ; desulphurization of high-sulphur coals; tests on the fusibility of ash of 'clinkering' coals; recovery of cyclopentadiene, styrene, coumarone, indene, etc., from coke-oven gas and tar; cyanogen compounds in coke-oven gas; preparation of ionexchange compounds from coal ; and analytical and other investigations on coal, lignite, coke, mine gases, briquetting, etc.

Assistance is given by the Fuel Research Institute in numerous problems of coal utilization to collieries, the Railway Board, Damodar Valley Corporation, Central Electricity Commission, and to central and provincial government departments. The field of consultations covers washability of coals, the instal. 
lation of washeries, coal and coke for the iron and steel industry, synthetic oil developments, pulverized fuels, manufacture of electrode carbons, coking properties of coals, locomotive fuels, coal evaluation, coal dust explosions, lignite developments, briquet. ting, wood distillation, spontaneous combustion, soft-coke manufacture, mine-air analysis, water analysis, and numerous other similar problems.

A number of publications arising out of work carried out at the Institute have been issued by the director, Dr. J. W. Whitaker, and members of the staff.

\section{MALARIA ERADICATION SCHEME, MAURITIUS \\ By DR. M. A. C. DOWLING Officer-in-Charge}

I

$\mathrm{N}$ the course of a large-scale experiment in malaria 1 eradication in progress in Mauritius, an interesting problem has come to light. In 1948 the Government of Mauritius, in conjunction with the Colonial Insecticides Committee, decided to carry out an experiment with residual insecticide. The aim of the scheme was the eradication of malaria from the island by means, in the first instance, of the application of residual insecticide to the internal surfaces of houses and outbuildings, followed later, if necessary, by auxiliary measures. By this means it was hoped to obtain a clear-cut comparison between the effects of different insecticide formulations, and also to discover whether house-spraying alone was sufficient to produce elimination of domestic Anopheles species. Accordingly, a research team was appointed by the Insecticides Committee to direct the experiment and interpret the results, and work began in November 1948.

Mauritius is an island of 720 square miles with a population of some 450,000 persons. Malaria was introduced halfway through the past century, transmitted by the African species, $A$. funestus and $A$. gambice. The former mosquito, breeding all the year round, was responsible for a large proportion of malaria eases, whereas $A$. gambice flourished only during the hot season, January-May. The first spraying began in the middle of January 1949, and was completed in May. In all, 75,829 houses (including churches, temples, stables, outhouses and other places harbouring mosquitoes were sprayed, representing some 377,000 rooms. A second spraying was carried out during August-December, in which 58,184 houses were sprayed. The insecticide preparations used were DDT in solution in kerosene, DDT wettable powder in aqueous suspension, and BHC wettable powder. $\mathrm{BHC}$ was abandoned early in 1950 , mainly on economic grounds.

The results so far obtained show a striking reduction in malaria incidence. Two spleen and parasite surveys have been carried out, the first before spraying

Table 1

\begin{tabular}{|c|c|c|c|}
\hline Survey & $\begin{array}{l}\text { No. of children } \\
\text { examined }\end{array}$ & $\begin{array}{l}\text { Spleen- } \\
\text { rate \% }\end{array}$ & $\begin{array}{l}\text { Parasite- } \\
\text { rate \% }\end{array}$ \\
\hline \multirow{2}{*}{$\begin{array}{l}\text { I. Befnre spraying } \\
\text { II. After 1 st spraying } \\
\text { III. After 2nd spraying } \\
\text { (incomplete) }\end{array}$} & $\begin{array}{r}3,585 \\
12,105\end{array}$ & $\begin{array}{l}34 \cdot 8 \\
15 \cdot 3\end{array}$ & $\begin{array}{l}9 \cdot 5 \\
2 \cdot 4\end{array}$ \\
\hline & 7,724 & $3 \cdot 2$ & 0.36 \\
\hline
\end{tabular}

began and the second during the last six months of 1949. A third survey is in progress, and the figures, although not yet completed, are included in Table 1 .

The vital statistics for the island, as would be expected, reflect this diminution in the disease by significant reductions in the total annual death-rate, the infant mortality and the numbers of malaria deaths. A brief summary of these figures is given in Tables 2-5.

Table 2. Total Annual Death-rates, 1934-49 Mean rate, $1934-48$ (per 1,000 mid-year population) $27 \cdot 2 \pm 3 \cdot 37$ Range (per 1,000 mid-year pepulation) Annual death-rate for 1949 (per 1,000 mid-year population) $20 \cdot 1-36 \cdot 1$ $16 \cdot 6$

Table 3. Infant Mortality, 1934-49

$\begin{array}{lc}\text { Mean rate, } 1934-48 \text { (per } 1,000 \text { live births) } & 150 \cdot 0 \pm 19 \cdot 2 \\ \text { Range, } 1934-48 & 113 \cdot 9-188 \cdot 0 \\ \text { Infant mortality-rate for } 1949 & 91 \cdot 0\end{array}$
Infant mortality-rate for 1949

$9 \mathrm{I} \cdot 0$

Table 4. Malaria Death-rate during the Epidemic First Six Months of Years $1934-50$

Mean malaria death-rate, 1934-48 (per 10,000 population)

10,000 for 1949

(per 10,000 for 1950$)$

$32 \cdot 2 \pm 8 \cdot 07$

$12 \cdot 9$

The total death-rate is, however, a more reliable figure than the malaria death-rate, and the first halfyear of 1950 shows a significant decrease on previous years.

Table 5. Comparison of Total Death-rates during First Six Month of Years 1934-50 (expressed as rates per annum) Mean rate, 1934-48 (per 1,000 mid-year population) Range, $1934-48$ 000 for 1949

$28 \cdot 0 \pm 4 \cdot 22$

$20 \cdot 6$

$16 \cdot 8$

A further series of figures which provides valuable information regarding the progress of the scheme is the results of examination of children born since the first spraying in their locality had been completed (Table 6). Although only the malarious coastal areas have been included in this survey, the parasite-rate among the children is very low.

Table 6

\begin{tabular}{|l|c|c|c|}
\hline \multicolumn{1}{|c|}{ Age group } & $\begin{array}{c}\text { Children } \\
\text { examined }\end{array}$ & $\begin{array}{c}\text { Positive } \\
\text { blood slides }\end{array}$ & $\begin{array}{c}\text { Parasite- } \\
\text { rate (\%) }\end{array}$ \\
\hline 0-3 months & 1,621 & 3 & $0 \cdot 19$ \\
4-6 months & 1,619 & 4 & 0.25 \\
7-12 months & 2,592 & 7 & $0 \cdot 27$ \\
Over 1 year & 613 & 1 & 0.16 \\
\hline Total & 6,445 & 15 & $0 \cdot 23$ \\
\hline
\end{tabular}

These encouraging figures suggest that the transmission of malaria is of a very low order. This is supported by the fact that the number of cases notified by hospitals and dispensarjes as being malaria during the seasonal months January-June of 1950 shows a reduction of 86.0 per cent on the previous record year of 1948. A system is also in operation whereby blood slides are taken by the dispensers from a large proportion of these cases prior to the administration of treatment, and examined in the laboratory for the presence of malaria parasites. Out of 1,700 slides so examined, only $53(3 \cdot 1$ per cent) were found to be positive. These figures show a very low parasiterate in spite of a heavy rainfall this summer, suitable in every way for the propagation of mosquitoes. Many of these cases are, no doubt, relapses of the disease.

Since the arrival of the team in November 1948, a careful check has been maintained on the mosquito population, both in adult and larval stages. As the 